\title{
Pendidikan Kesehatan Tentang Pencegahan Scabies pada Santri di Pondok Pesantren Modern Al-Hidayah Kota Jambi
}

\author{
Hasyim Kadri' ${ }^{1}$, Salvita Fitrianti ${ }^{2}$ \\ ${ }^{1,2}$ Program Studi S1 Keperawatan, STIKes Baiturrahim Jambi \\ Email : h451mkadri87@yahoo.com
}

Submitted : 04/12/2020

Accepted: 18/12/2020

Published: 11/01/2021

\begin{abstract}
A high prevalence of scabies is generally found in environments with high density of residents and interpersonal contacts such as Islamic boarding schools, prisons and orphanages. The impact arising from scabies caused by personal hygiene problems includes the frequency of bathing, washing hands, using soap or not, changing clothes and towels, clean bedding, hair hygiene, nail hygiene, dental and oral hygiene, foot and shoe care, eye hygiene, ear hygiene and nose hygiene. The clinical manifestations that are usually caused are itching which is usually severe and will get worse at night and there are blisters or small, thin bumps on the skin.The solution of this community service is to provide health education and scabies prevention simulations to change or increase students' knowledge about scabies prevention.The results obtained by the participants in following the activities of community service well all followed the activity sequence without leaving the venue, a total of 37 participants were santri wati, they enthusiastically asked questions and participated in practicing the activities taught and carried out simulations of prevention of scabies.
\end{abstract}

Keywords:, Al-hidayah modern islamic boarding school, health education, prevention of scabies

\begin{abstract}
Abstrak
Prevalensi scabies yang tinggi umumnya ditemukan di lingkungan dengan kepadatan penghuni dan kontak interpersonal tinggi seperti pondok pesantren, penjara dan panti asuhan. Dampak yang timbul akibat scabies yang disebabkan pada masalah personal hygiene meliputi frekuensi mandi, cuci tangan, memakai sabun atau tidak, penggunaan pakaian dan handuk bergantian, kebersihan alas tidur, kebersihan rambut, kebersihan kuku, kebersihan gigi dan rongga mulut, perawatan kaki dan sepatu, kebersihan mata, kebersihan telinga dan kebersihan hidung. Manifestasi klinis yang biasanya ditimbulkan yakni berupa gatal yang biasanya parah dan akan memburuk pada malam hari dan ada lecet atau benjolan kecil dan tipis di kulit.Solusi dari pengabdian masyarakat ini adalah memberikan pendidikan kesehatan dan simulasi pencegahan scabies untuk mengubah atau meningkatkan pengetahuan santri tentang pencegahan scabies. Hasil yang didapatakan peserat mengukuti kegitan pengabdian kepada masyarakat dengan baik semua mengkuti rangkayan kegitan tanpa meninggalkan tempat acra, total peserta 37 orang santri wati, mereka antusias bertanya dan ikut mempraktekan kegiatan yang di ajarkan dan melakukan simulasi pencegahan scabies.
\end{abstract}

Kata Kunci : pendidikan kesehatan, pencegahan scabies, pondok pesantren modern al-hidayah

\section{LATAR BELAKANG}

Prevalensi scabies di Indonesia menurut Depkes RI (2016) sebesar 5,60\%$12,96 \%$. Scabies di indonesia menduduki urutan ketiga dari 12 penyakit kulit tersering. Scabies sering terjadi di negara dengan iklim tropis, seperti Afrika Amerika Selatan, karibia, Australia tengah dan selatan dan asia.

Berdasarkan Laporan Dinas

Kesehatan Kota Jambi tahun 2018. Data penderita scabies di 20 Puskemas di Kota
Jambi dengan jumlah penderita scabies sebanyak 1.734 kasus, sedangkan Puskesmas yang terbanyak penderita penyakit scabies adalah adalah Puskesmas Olak Kemang dengan jumlah 548 kasus. Sedangkan laporan klinik yang ada di Pondok Pesantren Modern Hidayah tahun 2018 ada 3 penyakit terbesar yang ada di Pondok Pesantren Modern Hidayah adalah 1 scabies sebanyak 120 kasus, 2 ispa sebnyak 97 kasus, 3 diare sebnyak 31 kasus. 
Scabies dapat dipengaruhi oleh beberapa faktor risiko seperti rendahnya tingkat ekonomi, higienisitas yang buruk, hunian padat, promiskuitas seksual, tingkat pengetahuan, usia dan kontak dengan penderita baik langsung maupun tidak langsung (Handoko, 2010).

Menurut Rohmawati (2010) salah satu faktor resiko scabies adalah : sistem imun tubuh semakin rendah imunitas seseorang maka, akan semakin besar kemungkinan orang tersebut untuk terjangkit atau tertular penyakit scabies. Namun, diperkirakan terjadi kekebalan setelah infeksi. Orang yang pernah terinfeksi akan lebih tahan terhadap infeksi ulang walaupun tetap masih bisa terkena infeksi dibandingkan mereka (orang-orang) yang sebelumnya belum pernah terinfeksi scabies. fasilitas umum yang dipakai secara bersamasama dengan lingkungan padat penduduk, tidur bersama, dan berjabat tangan. Untuk mengatasi masalah yang terjadi dipondok pesantren diperlukan upaya pencegahan lanjut terhadap masalah yang terjadi ada penderita scabies.

Penularan penyakit scabies dapat terjadi biasanya melalui : kontak langsung, misalnya : tidur bersama, bermain bersama, perawat/dokter dengan penderita anak-anak dengan pengasuhnya, dan lain-lain. Alatalat tidur misalnya selimut, alas kasur (sprei), bantal. Pakaian, misalnya sering tukar-menukar pakaian. Handuk, misalnya handuk yang dipakai bersama, lingkungan yg kurang bersih dan ketersediaan air bersih (Irianto, 2014).

Berdasarkan hasil survey kepada santriyang dilakuakn di Pondok Pesantren Modern Al-Hidayahsantri mengatakan bahwa penyakit gatal-gatal atau scabies sudah sering terjadi pada anak pesantren karena mereka hidup secara bersamaan dapat terlihat dari kebiasaan santri seperti sering bergantian pakaian, handuk, baju,selimut, bantal dengan santri lain, jarang mengganti sprei, penggunaan sabun mandi secara bersamaan. Maka hal-hal ini dapat mempermudah penularan penyakit scabies.
Timbulnya penyakit tersebut disebabkan kurangnya pemahaman oleh santri tersebut serta kurangnya kebersihan diri, salah satu faktor yang dominan yaitu kehidupan bersama dengan kontak langsung yang relatif erat pada penderita scabies tersebut. Dan mereka hanya mengatakan bahwa jika terasa gatal-gatal diseluruh badan mereka langsung ke Klinik untuk mendapatkan pengobatan dan kalau sudah parah dibawa ke Puskesmas Pall 10.

\section{TARGET DAN LUARAN}

Target Luaran dalam kegiatan ini adalah Pendidikan kesehatan dan Demonstrasi pencegahan Scabies Santri Pondok Pesantren Modern Al-Hidayah serta menyusun program di KlinikPesantren Modern Al-Hidayah

\section{METODE PELAKSANAAN}

Pengabdian kepada masyarakat ini dilakukan pada pada tanggal 16 November s/d 07 Desember 2019di Pesantren Modern Al-HidayahKota Jambi. Adapun tahap pelaksanaan Pengabdian kepada Masyarakat ini melakukan pendidikan kesehatan, Demonstrasi pencegahan Scabies serta menyusun program di KlinikPesantren Modern Al-Hidayah

\section{HASIL DAN PEMBAHASAN}

Hasil yang dicapai dalam kegiatan ini antara lain : Pelaksanaan Pengabdian pada masyarakat dimulai dari pengajuan izin pelaksanaan kepada Kepala Pesantren Modern Al-HidayahKota Jambi. Sebelum memberikan pendidikan dan demonstrasi pencegahan Scabies terlebih diberikan penjelasan tentang kegiatan yang akan dilaksanakan dan meminta persetujuan. Kemudian diberikan pendidikan kesehatan tentang Scabies dan pencegahanScabiesPesantren Modern AlHidayahdan demonstrasi pencegahan Scabies kemudian dilanjutkan dengan menyusun program di KlinikPesantren Modern Al-Hidayah. Pelaksanaan kegiatan 
dilakukan di ruang aula Pesantren Modern Al-HidayahKota Jambi pada tanggal tanggal 16 November s/d 07 Desember 2019. Evaluasi pelaksanaan Pengabdian kepada masyarakat dibagi menjadi 3 evaluasi yaitu: Evaluasi Struktur, Penyuluhan tentangScabies, demonstrasi pencegahan Scabiesdan menyusun program di KlinikPesantren Modern Al-Hidayahyang berperan sebagai presenter dan instruktur adalah Ns. Hasyim Kadri, S.Kep, M.Kes dan yang berperan sebagai observer adalah Salvita Fitrianti .MKM.Semua anggota berperan secara baik dan sesuai dengan rencana. Pelaksanaan pengabdian ini dibantu oleh 3 orang mahapeserta yang bertugas sebagai fasilitator dan moderator. Evaluasi Proses, Selama proses berlangsung santri dan petugas klinik sangat antusias dan aktif dalam kegiatan dan diskusi. Sebanyak $85 \%$ peserta bertanya terkait dengan materi yang disampaikan. Selama proses berlangsung tidak ada peserta yang keluar masuk ruangan .Selama kegitan Presenter mampu berinteraksi dengan baik kepada seluruh peserta. Evaluasi Hasil, $85 \%$ peserta mampu memahami tentang materi yang disampaikan. Rencana Tindak lanjut yang perlu dilakukan untuk kegiatan ini : Melakukan kegitan dengan rutin dan terjadwal Klinik Pesantren Modern AlHidayahKota Jambi.

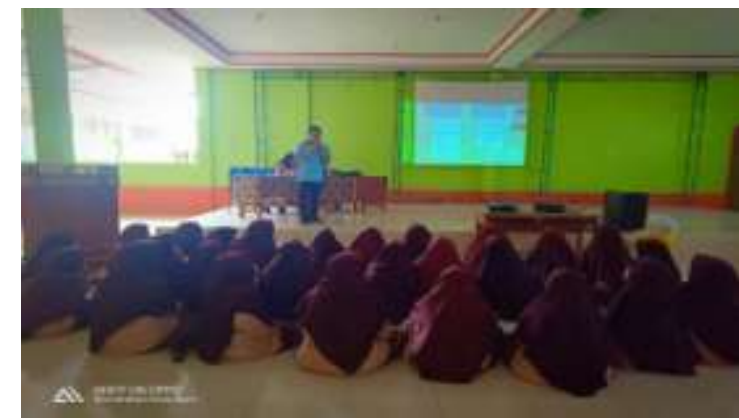

Gambar 1. Penyampaian materi tentang Scabies dan pencegahan Scabies

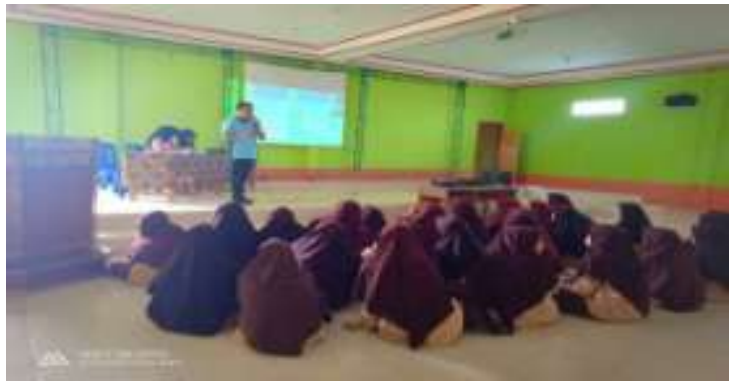

Gambar 2. Demonstrasi pencegahan Scabies

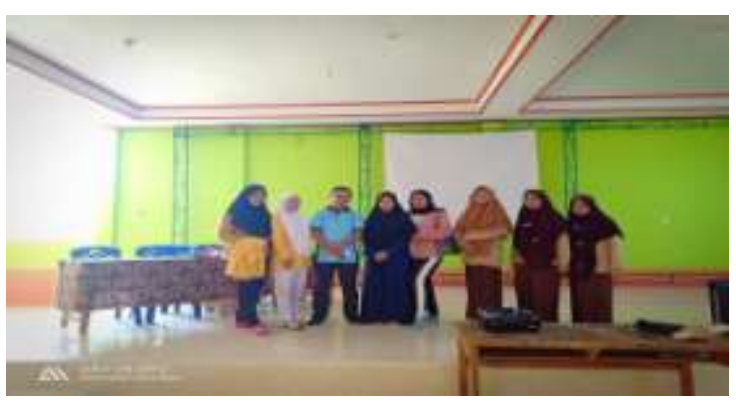

Gambar 3. Foto bersama sebagai dokumentasi

\section{KESIMPULAN DAN SARAN}

\section{Kesimpulan}

Pelaksanaan pengabdian kepada masyarakat di Pesantren Modern AlHidayahKota Jambi yang dilakukan oleh dosen STIKes Baiturrahim dan Mahasiswa berjalan dengan baik. Kegitan pengabdian kepada masyarakat yang dilakukan di Pondok Pesantren Modern Al-Hidayah Kota Jambi kepada 30 santri tentang pencegahan scabies pada santri yang dilakukan selama 17 hari dari tanggal 16 november s/d 07 desember 2019. Peserta yang megikuti kegiatan sangat antusias bertanya dan mengukuti simulasi dan rolpley.

\section{Saran}

Perlu dilakukan kegiatan secara rutin dan terjadwal khususnya pendidikan kesehatan di Pondok Pesantren Modern AlHidayah Kota Jambi.

\section{UCAPAN TERIMAKASIH}

Terimakasih yang tak terhingga kepada Sekolah Tinggi Ilmu Kesehatan Baiturrahim Jambi yang memberikan kemudahan dalam pelaksanaan penelitian ini. Selain itu penulis juga mengucapkan 
terimaksih kepada ketua RT. 16 Kelurahan Murni, Kota Jambi dan penulis juga mengucapkan terimakasih santri dan pimpinan Pondok Pesantren Modern AlHidayah Kota Jambi yang telah menerima dan membantu proses kegiatan pengabdian sehingga kegiatan ini bisa terlaksana dan berjalan lancar

\section{DAFTAR PUSTAKA}

Andareto Obi. (2015). Penyakit Menular di Sekitar Anda. Jakarta : Pustaka Ilmu Semesta.

Depkes RI. (2016). Angka Kejadian Masalah Scabies. Departemen Kesehatan Republik Indonesia.

Dinkes Kota Jambi. (2018). Angka Kejadian Masalah Scabies. Dinas Kesehatan Kota Jambi.
Hidayat, A.A.A. 2009. Metode Penelitian Keperawatan dan Teknik Analisis Data. Jakarta : Salemba Medika.

Kemenkes RI. (2014). Konsep Personal Hygiene Pada Anak-Anak. Kementerian Kesehatan Republik Indonesia.

Maharani. (2015). Penyakit Kulit. Yogyakarta : Pustaka Baru Press.

Notoatmodjo. 2012. Ilmu Kesehatan Masyarakat. Jakarta : Rineka Cipta.

Puspitasari. (2018). Asuhan Keperawatan Pada Pasien Dengan Gangguan Sistem Integumen. Yogyakarta: Pustaka Baru Press.

Susanto R Clever. (2013). Penyakit Kulit dan Kelamin. Yogyakarta : Nuha Medika

Puspitasari. (2018). Penyakit Kulit. Yogyakarta : Pustaka Baru Press. 